\title{
It is No Longer Possible to Go Back Home: Crossing Borders and Liminal Space in Thomas King's "Borders"
}

\section{Lamiaa Hassan Ibrahim Abdulaal*}

Borders play an essential role culturally, politically, and economically because they create the other based on power relations. They locate the division between things and people by keeping some of them in and the others out of social and cultural norms. Those who dominate create borders to distinguish between races, genders, and socioeconomic classes. In Borderland La Frontera, Gloria Anzaldua $(1987,3)$ remarks that the whites - the dominant group - have the power to draw the borderlines, and they are the only legitimate inhabitants. The production of a border is never a neutral act. It is always political. Being on borderlands helps to discover and manifest new ways of negotiating a multiple subject position. Therefore, the dilemma that faced indigenous and immigrant people can be illustrated through the concept of border.

Borders call into question the validity of the structure of power. National identities have access to a multiplicity of perspectives and bridge the unnatural divide form through interaction with borders. Borders enhance the sense of national identity by creating a contact zone which enforces negotiation between differences. They redefine self-other relations. While they divide self from others, they act as places of encounter between them. Borders, as a contact zone, liberate the subordinate or marginal identity and enable him/her to resist the dominant power. Homi Bhabha (1994) calls this contact zone the "Third Space." It helps the interaction between different cultures and identities (56). Therefore, borders are significant not only because they enhance the sense of national identity but also because they serve as a contact zone where the interaction between the dominant and the marginal is possible.

In "World and the Home," Bhabha $(1997,445)$ remarks that the third space, as positive and empowering space, constructs hybrid identity. Such a hybrid identity threatens dominant cultural authority. This identity is left in a continually unfixed state of existence, or in "in-betweenness." Therefore, the hybrid identity can problematize the boundaries and create the in-betweenness

\footnotetext{
* Associate Professor of English Literature in the Department of Foreign Languages, Faculty of Education, Tanta University.

Cairo Studies in English - 2021(1): https://cse.journals.ekb.eg/
} 
state. This state of in-betweenness leads to what Bhabha calls "the unhomeliness." For Bhabha, the construction of hybrid identity is an "estranging sense of the relocation of the home and the world in an unhallowed space." In our societies, many people suffer because of the incurable feeling of homelessness created by the breakdown of family structures and a sense of global culture that denies the security of national boundaries. In this sense, the border becomes a site of resistance in which those people need to dismantle it. As borders are socially constructed, they can also be deconstructed and leave the hybrid identity in a liminal space.

Liminality is an essential category related to the concept of cultural hybridity. It plays a powerful role in describing borders and border crossings. In 1909, Arnold Van Gennep introduced the concept of liminality in his book Rite of the Passage. Liminality refers to the unstable social position of the person who changes. Van Gennep remarks, according to Arup Ratan Chakraborty (2016, 147), that during the transition, the state of that person remains uncertain because he or she is separate from a clearly defined state in the past and not yet incorporated into a clearly defined future state. In 1960, Victor Turner widened the concept and introduced a new concept that is related to modern rituals. Both Gennep and Turner explain liminality as a state where the individual can claim his self by moving in an ambiguous state called the threshold stage. They name three phases in liminal space: the first stage is the uncertainty or the ambiguous state, followed by the possibility to adapt to new norms, and the final one is the pre-integration. According to Turner $(1995,125)$, "Liminality is thus the inbetween and marginal state, in which an individual resides before becoming integrated into his or her new position in society." In other words, the liminal subject is neither in its previous position nor in the newly integrated one.

Liminality opens up the possibility of expressing different social positions. This social position enables the marginal to resist the dominant culture. This position is related to borders. In other words, this liminal space is an empowering and transformative space. It is the area that manages the relationship in the social structure. It facilitates understanding the concept of borders, either geographical or social. In more general terms, it marks the place, line, or border at which a passage can be made from one space to another. Liminal space, as an in-between cultural structure, has an essential role in social interactions. As a threshold, liminal space helps individuals to negotiate their social status in which one is either rejected or welcomed to the new social sphere.

Postcolonial criticism of nationalism enhances the understanding of the concept of liminality in which it describes a state of being on the border in the 
sphere of identities and discourses. In Key Concepts in Postcolonial Studies (2000, 117), Bill Ashcroft, Gareth Griffiths, and Helen Tiffen point out that "The importance of the liminal for post-colonial theory is precisely its usefulness for describing an 'in-between' space in which cultural change may occur." Therefore, liminality enables social interactions and self-construction through hybridization. Bhabha refers to liminality as a transitory, in-between state which characterized by indeterminacy, ambiguity, hybridity and change. It is a site that represents a strategic value. In particular, it indicates a relationship with the social standards to provide them with a capacity to challenge the stereotypes. Bhabha (1994, 5) considers liminal space a symbolic interaction, or "the connective tissue" that establishes the differences between binaries such as upper/lower and black/white.

Bhabha argues that liminality emphasizes a complex process of differentiation and the genesis of new categories. The question of otherness then becomes that of the incapacity of a normative system to produce a new reference system of identification. According to Bhabha, the two subjects that incorporate, in this process, are "mobilized in the passage through Third space" $(1994,53)$. Being at the border, in the liminal process, suggests that the two subjects are in a relationship, and we cannot understand any of them singularly. Turner (1995, 95) remarks that individuals in the liminal space are "betwixt and between." This calls into question the reified concept of unity, authenticity, and origin. Those individuals do not belong to their previous position, and they are not yet part of the new society.

Liminal space describes a state of fluidity that helps to challenge the construction of otherness. Liminality, in this sense, offers a way for individuals to examine themselves by comparing it with others. As liminality creates an inbetween space, it helps the marginal cultures to speak and represent themselves. Bhabha $(1994,2)$ notes that the in-between space offers a ground for explaining strategies of establishing individual and communal selfhood. This space initiates a new sign of identity and represents a site of collaboration and contestation that help the act of defining the society itself. Therefore, liminality shapes the border space that redefines the center and the margin. The liminal state helps define a dynamic relationship with them and their norms. Moreover, the border expresses a territory of national dominion. Also, it creates cultural identity at different levels, such as regional, local, and public (Mayer 2014, 14).

Mahesh Sharma $(2013,114)$ asserts that living on the border allows us to rethink the formative criterion of class, community, and identity. It is full of contradiction and ambivalence. They both separate and join different places, so 
they provide an immense possible site of representation which allows the subaltern to speak. Liminality, in other words, provides a space to stand outside the center and challenge its authority. Thus, borders play a central role in the writings of Aboriginal or indigenous authors. For these authors, international boundary, such as that between Canada and the United States, is more than a geographical division. It is a distinction between Canadian national identities in contrast to the presence of the United States. Canadian writers, such as Thomas King, emphasize the transformative power of the borderlands and the importance of liminality in asserting the identity of their people.

Thomas King's short story "Borders" (1993) takes place in Canada-U.S. borders. In "Borders," King portrays the experiences of a mother and her young son (the narrator) caught in no man's land between Canada and the United States, defending their Blackfoot identity. The Blackfoot are Indian tribes that inhabit North America. The un-named mother wants to visit her daughter, Laetitia, in Salt Lake City in the USA. She refuses to declare her citizenship either as Canadian or American; instead, she proclaims herself as Blackfoot. Consequently, both mother and young son have to stay in-between the CanadianUS border. Throughout this story, King differentiates between two kinds of borders: physical and metaphorical. The first one occurs between Canada and the USA, while the second refers to the border between someone's identity and citizenship.

In "Borders," the mother is concerned about her tribal identity. She refuses to claim another identity. She and her son find themselves sleeping in the duty-free parking lot, the only place they can stay without declaring their citizenship. The narrator tells the duty-free store manager that they have "nowhere to go, that neither the Americans nor the Canadians would let us in. He laughed at that and told us that we should buy something or leave" (King 1993, 140). The duty-free store becomes a liminal space for the narrator and his mother, where he realizes that neither Americans nor the Canadians would let them in because his mother is very proud of her identity. The liminal space of the border helps the mother to bridge the gap between her and her son by telling him all kinds of traditional stories to claim their unique identities. These indigenous stories about the origins of the world recounted to her son will serve as a means of resistance. The return to the indigenous story is a liminal phenomenon. These Indigenous stories represent counter-narratives that help the mother to connect the past with the present. The mother, in this sense, rebuilds the pride of being Blackfoot by refusing to assimilate, and at the same time, she helps her son to give back his sense of belonging. In this liminal space, she transmits the indigenous traditions 
by using oral stories. These traditional stories help the unnamed narrator, who himself is on the threshold of adulthood, to connect to his own origin and be able to understand his position as an Indian on the border.

King focuses on the struggles of Canadian and American indigenous communities. He remarks that indigenous people have the right to claim their own identity. Jennifer Andrews and Priscilla Walton (2006, 605) remark that "Bing inside and outside the borders does not mean that one is immune to or from them; rather, it suggests that from in-between, one can view either sides, perhaps rejecting both, but also acknowledging how those sides influence one's own spatial position." This state of being in-between enables the marginal to challenge the authority of the center. "Borders" highlights the connection between the notion of tribal identity and struggles for border-crossing rights. The mother believes that she has the right to cross the border without claiming any citizenship. By doing this, she challenges the authority of the dominant culture and claims that the border is her ancestral homeland. Claudia Sadowski-Smith $(2008,73)$ points out that indigenous people consider borders as "sacred, home to deities, ceremonial sites, and generations of ancestors, even when histories of displacement or the loss of the homelands may be part of a particular tribal or national experience."

King emphasizes the importance of the liminality of the borders in the title of his short story. It underlines the central significance of borders in King's narration, plot, and climax, which are closely related to the Canada-U.S. borders. King employs humor, in this complex situation, as a subversive weapon to challenge the power system and to give the mother a space to claim her own unique identity, neither American nor Canadian, but a "Blackfoot side" (King 1993, 136). The unnamed mother enhances the sense of liminality because she acts as a representative of her indigenous people. Taiaiake Alfred $(1999,135)$ argues that traditional indigenous stories form the narrative backbone of their culture. He adds, "The formation of a new indigenous intelligentsia that understands the essence of commonality of the traditional teachings is crucial to reforming politics and society." Therefore, the liminal zone serves as a safe space allowing indigenous people to find expression and advocate their uniqueness. In "Borders," the liminal zone allows the mother to create a space of freedom, where she and her son can occupy the space that deconstructs the colonial manner.

The connection between both border and liminality is obvious. In "Borders," it functions as a place that enables the mother to emphasize her cultural identity. It opens a space for the mother to teach her son a lesson about the uniqueness of 
their heritage. During the dilemma of crossing the border, the mother tells her son the traditional stories: "She'd tell them slow, repeating parts as she went, as if she expected me to remember each one" (142). In her essay "Beyond Border Binaries: Borderlines, Borderlands, and In-betweenness in Thomas King's Short Story 'Borders," Evelyn Mayer $(2011,79)$ remarks that the mother uses the involuntary exile in "no man's land" to transmit some traditional values to her son. The mother insists on transferring traditional values to her young son in this complex situation because she realizes the power of the border and the importance of keeping one's cultural identity in this situation. Moreover, being in "no man's land" of the mother and her son signifies a refusal to locate themselves within the discourses of the nation. In this respect, this border space can be, in Bhabha terms, a "third space," or liminal space.

The fluidity of borders implies the idea of in-betweenness. William Herbert New $(1998,29)$ explains that in King's story, borderlines can turn into thresholds, especially for the next generation, in which borders transcend beyond the limitation of citizenship. King emphasizes the importance of tradition and culture in crossing borders. Therefore, cultural identity is the site of inbetweenness in "Borders." The mother represents the traditional pride of the Blackfoot tribe. She speaks to her daughter in Blackfoot's language, whereas Laetitia answers her in English. The mother's use of indigenous language instead of English highlights her sense of belonging to the Blackfoot's tradition. The mother recognizes herself as a Blackfoot, while her daughter identifies herself as an English-speaking American - because her father is American. When Laetitia decides to leave her home and goes to the USA to find a job, her mother tries to convince her to stay at home. The narrator observes that "You can still see the mountain from here," my mother told Laetitia in Blackfoot. "Lots of mountains in Salt Lake," Laetitia told her in English (King 1993, 133). Coutts, the border city, represents a liminal space in this situation that opens a space for both mother and daughter to negotiate their sense of identity. In this border city, Blackfoot appears as the center of the mother's cultural identity, especially in the use of Blackfoot's language, while her daughter is struggling in identifying her own identity.

King emphasizes tribal claims to border areas as an ancestral homeland. Sadowski-Smith $(2008,88)$ points out that “All of King's work on the Blackfoot reveals his keen understanding of connections between attempts to preserve tribal sovereignty and notions of aboriginal residents in border areas." $\mathrm{He}$ highlights connections between notions of tribal nationhood and struggles for border-crossing rights. The geographical location along the Canada-US border, 
which is located in the Alberta-Montana borderlands, is an in-between space where, as Evelyn Mayer (2011) remarks, "the past, present, and future of Canadians and Americans merge in particular First Nations in Canada and Native Americans" (68). The narrator's father is American: "Our father was from Rocky Boy on the American side" (King 1993, 131). So he and his sister think that they can cross the border as they please. The narrator highlights this point of view: "Dad's American," Laetitia told my mother, "so I can go and come as I please" (131). But this was not the case with the mother who insists on her tribal nationhood. She realizes that her role is to preserve her tribal identity and to transmit it to her children. The daughter, on the other hand, believes in the fluidity of the borders because she belongs to both sides.

King, an American-Canadian writer, was born in The United States from a Greek mother and Cherokee father and then he immigrated to Canada. He describes himself as a Native writer who writes for Native audiences to provide them this sense of being on the inside. Teresa Gilbert (2006) remarks that oral discourse helps King not only to speak to Native communities but also to make the voices of such communities heard by a broad non-Native audience (3). Thus, King's "Borders" can be understood in the concept of liminality in which the characters live in a transitional space that exists at the interaction between two cultures or stages. Reingard Nischik points out

In this intensified liminal state - see for example, the catalyzing behavior of the often identity-challenging border guards - being in between two countries/states, inside and outside the borders, the characters in their transitional state are made intensely aware of the demarcating and separating, yet, at the same time, also bridging and enabling function of borders. $(2016,91)$

By using the Blackfoot and the English language between the mother and her daughter in this transitional space, King tries to enhance the importance of bridging the gap between the two cultures. For King, the border is a liminal space, a contact zone where the interaction between these two different cultures is possible.

The liminality of the border represents both inside and outside the power system. That is to say, liminality is viewed, with suspicion, by any power system. Mihai Sparious (2004) asserts that when power moves into a liminal space, this space becomes a border, and the limen moves outside it. That is why power fascinates and horrifies the limen because it conceptualizes as nothingness 
(being always out of reach) (70-1). In this sense, the mother, in "Borders" is able to challenge the official border crossing rules and confirm her Blackfoot view of international borders. King complicates the notions of borders, citizenship, and national identity. Thus, as Sparious suggests, liminality can subsume and transcend a dialectics of margin and center because, unlike the margin, it may not lead back to the center. On the contrary, it may lead away from it in steady and irreversible fashion (70). The border for Canadians, in general, represents a location of self-protection as well as a defense line from American imperialism. In "Borders," the Canadian-US border, for the Blackfoot mother, is a site of resisting the colonial stereotype, and a space to be heard.

Hence, "Borders" is a story of resistance which introduces a deeper understanding of Native people in the past and present. In postcolonial terms, the production of border-narratives enables the individual to testify to the oppressive and traumatic experiences that are so often entailed in counters with the border. Consequently, many border-narratives are acts of writing-back to the oppressive discourse. King's border narrative helps him not only to speak to Native communities but also to make the voices of such communities heard by the non-Native audience. The border narrative helps to deconstruct the binary opposition that is created by the borders. David Stirrup and Jan Clarke (2015) assert that "Border studies of course long has demonstrated the ways in which cultural representation and production can effect, at least metaphorically, the deconstruction of binary structures implied by a border" (2). King expresses Native's concerns about racial discrimination and stereotype. In "Borders," the liminality of the border helps the mother to introduce a counter-narrative to this stereotypical image.

The in-betweenness of the border opens a space for the mother to challenge the authority and stereotypical attitude of both Canadian and American guards. Such an attitude towards indigenous people creates a feeling of insecurity and ambiguity. Therefore, the border is arbitrary for the narrator. He thinks that "The border was actually two towns, though neither one was big enough to amount of anything" (King 1993, 133). Mayer points out

Borders often defy intuitive logic, particularly if they are not geographical borders, such as mountain ranges or rivers. This arbitrariness leaves a person with a puzzled sense of why here is here and there is there, which also holds true for the Canada-US border. $(2013,14)$ 
The narrator reflects this arbitrariness: "Just hearing the names of these towns, you would expect Sweetgrass, which is nice name ... would be in the Canadian side, and that Coutts, which sounds abrupt and rude would be on the American side. But this was not the case" (King 1993, 134). Moreover, this arbitrariness of the border reveals the ambivalent and uncertain relationship between Canada and the USA. The young narrator observes the difference between Canadian and American guards. He sees the Canadian as a nice woman and the Americans as aggressive cowboys. King highlights this idea throughout the whole short story. The American guard appears cruel and rude while the Canadian guard is nice and affectionate. He describes The American border guards as "swaying back and forth like two cowboys headed for a bar or gunfight" (135), whereas "the Canadian border guard was a young woman, and she seemed happy to see us" (138). The American guards were rude and aggressive towards the mother and her son. They reflect a colonial vision about the Natives, either Canadian or Americans. The Canadian guard, on the other side, was sympathetic to the mother's situation, although she does not help her. She tells her: "I Know," said the woman, "and I'd be proud of being Blackfoot if I were Blackfoot. But you have to be American or Canadian" (138-9).

This situation highlights the paradox within the Canadian national identity. For the Canadian guard, the indigenous people are not a citizen. It is not enough to be a Blackfoot; the mother needs to declare citizenship, either American or Canadian. According to Laura Peters (2003), "The presence of the indigenous people serves as a constant reminder that Canadians are not indigenous in that they are not of the land, while the indigenous - as "Borders" so powerful reveals - are not Canadians' (197). King challenges both Canadian and American perspectives of the border that delimit the indigenous identity. Therefore, crossing either physical or cultural borders is significant for the indigenous people.

The crossing of the national border between Canada and the USA is essential in King's story because the border, in this case, is simultaneously powerful in delineating the process of identity formation. Throughout the crossing borders, indigenous writers engage with the colonial heritage and its contemporary manifestations. They can challenge the colonial history as well as the present issues. For Karl Hele (2008), the border is a crucible where a conflicting current of identity, history, and culture shape local and national communities (xxiii). The stage of liminality helps to examine one's self in comparison to others. Therefore, the concept of border enhances the process of identity formation. Alexander Pett $(2001,35)$ asserts that crossing Canadian-American borders have a history of 
oppression. Both Canada and the United States need one another to define themselves. For Canadians, the border is central to identity. Canadians differentiate themselves from Americans. In this sense, the border is viewed as a necessary protective shield to help maintain Canadian uniqueness and identity. Thus, the border often symbolizes Canadian efforts to resist U.S. cultural, political, and economic intrusion. King insists on this idea in "Borders". When the mother decides to visit her daughter, she bought new tires for the car and she put on her blue dress with the green and yellow flowers and asked her son to dress up too because she "did not want us crossing the border looking like Americans" (King 1993, 133). Her main aim is to distinguish herself and her son from Americans. She is very proud of her identity.

The impossibility in King's story of crossing borders challenges the acceptance of differences and enhances its power. Throughout the experience of crossing borders, King highlights the importance of these borders for the indigenous people. He attempts to introduce these borders as liminal spaces where the indigenous people can experience being insiders rather than outsiders by experiencing the power to represent themselves. King, in "Borders," emphasizes that crossing the Canadian-US border helps the mother and her daughter to cross their borders. For King, this in-between space that helps the mother to transmit her native traditions to her son, and at the same time, it is the space where Laetitia crosses the border into adulthood. Although the mother refused to let her go at the beginning, and she tries to convince her to stay at home, she realizes later that her daughter has to cross her border:

Then there were the fine points to Laetitia's going. She had not, as my mother liked to tell Mrs. Manyfingers, gone floating after some man like a balloon on a string. She hadn't snuck out of the house either and gone to Vancouver or Edmonton or Toronto to chase rainbows down alleys. And she hadn't been pregnant. "She did real good". (King 1993, 131)

Laetitia lives in this in-between space for a while to be able to find her real identity at the end. She resembles the coyote in indigenous' traditional stories. She wanders to be able to find reconciliation with her origin.

For Gloria Anzaldua (2009), transgressing borders are more than crossing a line. We must be willing to break apart our old worldviews and reassemble them into something that allows us to navigate, survive, and bridge the liminal territory between binaries. It also is not something that begins and ends with the 
crossing of a border: it is an open-ended and fluid process. It is not an act of breaking from the old by crossing into the new, but rather an assemblage of both old and new, a re-mixture from both sides of the binary (247). Laetitia is able to cross the physical border because she belongs to both sides. But she finds it difficult to cross the cultural border because she was uncertain about her cultural identity and the relationship between this cultural identity and the idea of citizenship. At the beginning of the story, she left her home despite the refusal of her mother. Because she situated herself with the mainstream American culture, she denied her indigenous culture. Laetitia's approach to her indigenous culture reflects the stereotype of the standard American culture. Therefore, leaving home is essential for her to cross this border and be able to value her heritage. Both mother and daughter, at the end of the story, can cross their borders and bridge the differences between cultures and generations. Thus, "Laetitia said she was thinking about moving back, and Mom told her to do as she pleased, and Laetitia said that she would" (King 1993, 144).

Both Laetitia and her mother appear as the classical Native trickster who may be both hero and anti-hero. The trickster tries to fix the world, but this attempt may turn out to have beneficial, chaotic, or disastrous effects. Reingard Nischik (2012) asserts that tricksters exist outside any norms and rules. Anything seems possible with them. They open up liminal spaces of imagination that invite readers to transgress borderlines and reevaluate received cultural tenets (41). The liminal space of border is considered a counter-power that helps the indigenous to pass over being on margin. Arnold Davidson, Priscilla Walton, and Jennifer Andrews, in their book Border Crossings: Thomas King's Cultural Inversion (2003), illustrate that King emphasizes that the border is "a figment of someone else's imagination" (13). This figment is a dynamic force to make Natives' voices heard. Natives recognize the fluidity and uncertainty of borders. They are unstable and elastic. For King, they are merely illusion. In "Borders," the mother challenges this imagination, which helps her daughter and son to cross their borders. Finally, the narrator understands the position of his mother. He tells the reader: "Pride is a good thing to have, you know. Laetitia had a lot of pride, and so did my mother. I figured that someday, I'd have it, too" (King 1993, 140).

National borders ignore and erase the Natives' presence. Davidson, Walton, and Andrews explain that:

from a Native view, borders always were in flux, signifying territorial space that was mutable and open to change. The borders that presently exist ignore the Native peoples, who are often cut off 
from one another as a result of a line that has been drawn through their land. $(2003,16)$

King distinguishes between the real and imaginary of Natives' relation to borders by looking to this relation in different contexts. People's identities nowadays are no longer seen as fixed, but rather in a state of flux. Concepts such as difference, ambivalence, and hybridity exist at the borderlines, and postcolonial migrants challenge the binary categories and traditional identities that simultaneously relate to the East and the West. Therefore, the discourse about minorities is based on creating borders. Anzaldua (1987) points out that borders "set up to define the places that are safe and unsafe, to distinguish us from them" (25). In creating such borders, there is "no man's" land that travelers have to cross to pass from one place into another. Bhabha (1994) states that this process of crossing is a stage of transition: "the beyond is neither a new horizon nor a leaving behind of the past ... we find ourselves in the moment of transit where space and time cross to produce complex figures of difference and identity, past and present, inside and outside, inclusion and exclusion" (217). King captures the same experience in "Borders," which offers an explanation of the consequences of colonialism that are ignored for a long time. Simultaneously, he shows how many borders exist in daily life and how hard it can be to cross some of them.

At the end of this story, the mother manages to use the no man's land or the liminal space of the border to teach her son a lesson about his cultural identity. She successfully crosses the border because of the attention of the media: "Early the next morning, the television vans began to arrive, and guys in suits and women in dresses came trotting over to us, dragging microphones and cameras and light behind them" (King 1993, 142). King shows us that the experience of being on the liminal space of the borders helps the narrator, as well as the mother, to claim his identity. The narrator understands the meaning of being at home. $\mathrm{He}$ tells us: "Every so often one of the reporters would come over and ask me questions about how it felt to be an Indian without a country. I told them we had a nice house on the reserve" (142-43). The narrator learns how to appreciate his home and his cultural heritage.

While crossing the Canada-US border, a mother and son share a transforming experience. As they pass through barriers and bridges, contact zones and zones of resistance, the mother makes a convincing case for the indigenous rights of her people, the boy acquires a new respect for his identity, and readers are treated to an explanation of the contradictory perspectives of those who inhabit either side of the border and those who attempt the border crossing. In the end, the 
mother and her son cross the border as Blackfoot. The mother maintains her unique identity in spite of the power of the border and border guards, thus redefining what Robert Holub (1992) defines as set of relationships distributed throughout society, affecting individuals in various and unequal ways (70). King's portrayal of the crossing of the Canadian-US border is, in one sense, a criticism of an atavistic power structure that needs to be dismantled. But in another sense, it is a vision that offers hope. The Canada-U.S. border fades when the narrator looks back at the end of the story: "I watched the border through the rear-view window until all you could see were the tops of the flagpoles and the blue water tower, and then they rolled over a hill and disappeared" (King 1993, 145). King's story not only celebrates the dignity of indigenous peoples and their resistance to the arbitrariness of borders but also advocates for growth, wisdom, and perhaps, future change.

\section{Works Cited}

Alfred, Taiaiake. 1999. Peace, Power and Righteounes, an Indigenous Manifete. Ontario: Oxford University Press.

Andrews, Jennifer and Priscilla Walton. 2006. "Rethinking Canadian and American Nationality: Indigeneity and the 49th Parallel in Thomas King." American Literary History 18(3): 600-17.

Anzaldua, Gloria. 1987. Borderland La Frontera: The New Mestiza. San Francisco: Spinster Aunt Lute.

-----. 2009. “(Un)natural bridges, (Un)safe Spaces'. In The Gloria Anzaldua Reader, edited by Ana Louise Keating. Durham: Duke University Press, 243248.

Ashcroft, Bill Gareth Griffiths and Helen Tiffin. 2000. Key Concepts in Postcolonial Studies. London and New York: Routledge.

Bhabha, Homi. 1994. The Location of Culture. London and New York: Routledge.

----. 1997. “The World and the Home.” In Dangerous Liaisons: Gender, Nation, and Postcolonial Perspectives, edited by Anne McClintock, Aamir Mufti, and Ella Shohat, 445-455. Minnesota: University of Minnesota Press.

Chakraborty, Arup Ratan. 2016. "Liminality in Post-Colonial Theory: A Journey from Arnold Van Gennep to Homi K. Bhabha." Anudhyan: International Journal of Social Sciences $1(1)$ : 145-153. https://www.rnlkwc.ac.in/pdf/anudhyan/volume1/. 
Davidson, Arnold, Priscilla Walton and Jennifer Andrews. 2003. Border Crossings: Thomas King's Cultural Inversions. Toronto: University of Toronto Press.

Decker, Jessica Elbert and Dylan Winchock. 2017. "Introduction: Borderlands and Liminality Across Philosophy and Literature." In Borderlands and Liminal Subjects: Transgressing the Limits in Philosophy and Literature, edited by Jessica Elbert Decker and Dylan Winchock, 1-18. Cham: Palgrave Macmillan.

Gennep, Arnold van. 1909. Les rites de passage. Paris: E. Nourry.

Gilbert, Teresa. 2006. "Written Orality in Thomas King's Short Fiction.” Journal of Short Story in English 47: 2-10. http://journals.openedition.org/jsse/792.

Hele, Karl. 2008. Introduction to Lines Drawn upon the Water: First Nations and the Great Lakes Borders and Borderlands, edited by Karl Hele, xiii-xxiii. Waterloo: Wilfrid Laurier University Press.

Holub, Robert. 1992. Crossing Borders: Reception Theory, Poststructuralism, Deconstruction. Wisconsin: University of Wisconsin Press.

King, Thomas. 1993. "Borders." In One Good Story, That One, 131-148. Minnesota: University of Minnesota Press.

Mayer, Evelyn. 2011. "Beyond Border Binaries: Borderlines, Borderlands, and In-betweenness in Thomas King's Short Story 'Borders'." International Journal of Canadian Studies, 43: 67-82. https://doi.org/10.7202/1009455ar.

----. 2014. Narrating North American Borderlands: Thomas King, Howard F. Mosher, and Jim Lynch. Bern: Peter Lang Edition.

New, William Herbert. 1998. Borderlands: How We Talk About Canada. Vancouver: University of British Columbia Press.

Nischik, Reingard. 2016. Comparative North American Studies: Transnational Approaches to American and Canadian Literature and Culture. New York: Springer.

-----. 2012. “Wide-Angle Shots' Thomas King Short Fiction and Poetry.” In Thomas King: Works and Impact, edited by Eva Gruber, 35-54. Rochester, New York: Camden House.

Pett, Alexandra. 2001. "Thomas King's "Borders": The Difficulty of U.S./Canada Crossings." Textura, no. 5: 35-40.

Peters, Laura. 2003. "Thomas King and Contemporary Indigenous Identities." In Beyond the Borders: American Literature and Postcolonial Theory, edited by Deborah L. Madsen, 195-206. London: Pluto Press. 
Sadowski-Smith, Claudia. 2008. Border Fictions: Globalization, Empire, and Writing at the Boundaries of the United States. Virginia: University of Virginia Press.

Sharma, Mahesh. 2013. "The Liminality of Contemporary Culture." Bodhi: An Interdisciplinary Journal 6, no. 1: 109-119. www.ku.edu.np/bodhi.

Sparious, Mihai. 2004. Global Intelligence and Human Development: Toward an Ecology of Global Learning. Cambridge, Massachusetts, and London: MIT Press.

Stirrup, David and Jan Clarke. 2015. "Straddling Boundaries: Culture and the Canada-US Border." Comparative Americans Studies 13, no. 1-2 (June): 115.

Turner, Victor. 1995. The Ritual Process: Structure and Anti-structure. New Brunswick: Aldine Publication Company. 